\title{
Effects of inter-specific density and food supply on survivorship and growth of newly settled benthos
}

\author{
Roman N. Zajac ${ }^{1}$, Robert B. Whitlatch ${ }^{2}$, Richard W. Osman ${ }^{3, *}$ \\ ${ }^{1}$ Graduate Program in Environmental Sciences, Department of Biology and Environmental Sciences, The University of New \\ Haven, 300 Orange Avenue, West Haven, Connecticut 06516, USA \\ ${ }^{2}$ Marine Sciences Department, The University of Connecticut, Avery Point, Groton, Connecticut 06340, USA \\ ${ }^{3}$ Academy of Natural Sciences, Benedict Estuarine Research Laboratory, Benedict, Maryland 20612, USA
}

\begin{abstract}
Using a laboratory model system comprised of newly settled oysters Crassostrea virginica and established fouling species (Botrylloides sp. initially, and others including Styela clava and Ciona intestinalis as the experiment progressed), we tested how differences in food supply and competitor density may affect post-settlement survivorship and growth of sessile marine invertebrates over a $44 \mathrm{~d}$ period. After $15 \mathrm{~d}$, results were mixed but indicated that both food and density conditions affected growth and survivorship significantly, with some suggestion of high food levels ameliorating high density effects. However, $44 \mathrm{~d}$ after settlement, oysters had reduced survivorship and growth when competitors were present regardless of food level. This study suggests that localized food depletion by juveniles and/or adults of resident species may have a negative effect on recruitment in fouling communities, even when space is not limiting
\end{abstract}

\section{INTRODUCTION}

For benthic fauna with planktonic larval stages, recruitment success may be determined by factors (e,g. current regimes, predation) in the water column prior to settlement (e.g. Ketchum 1954, Keough 1983, Butman 1985. Gaines et al. 1985) and/or factors which exert their effects at the time of settlement and shortly thereafter. The latter include the amount of available space (e.g. Roughgarden et al. 1985), habitat structure (e.g. Dean 1981, Keough \& Downs 1982, Bros 1987, Stocker \& Bergquist 1987), and the presence of competitors and/or predators (e.g. Sutherland \& Karlson 1977, Dean \& Hurd 1980, Gallagher et al. 1983, Whitlatch \& Zajac 1985, Woodin 1985). In previous studies (Osman et al. 1989) we were able to demonstrate experimentally that newly settled individuals of the oyster Crassostrea virginica suffered reduced survivorship and growth when competing with a variety of sessile invertebrates. Our observations suggested this was a consequence of local reductions in food resources by competing species. Here, results are presented from a laboratory experiment designed to isolate effects of food supply and competitor density on the survivorship and growth of newly settled oysters.

\footnotetext{
- Authorship in reverse alphabetical order
}

\section{MATERIALS AND METHODS}

At the initiation of the study (July 1987), the encrusting ascidian Botrylloides sp. was the dominant competitor on $10 \times 10 \mathrm{~cm}$ plastic panels being held in the field and was used as the initial competitor in the experiment. (It is uncertain whether the Botrylloides species concerned is $B$. leachior $B$. diegensis and we are therefore reluctant to assign it to a specific species.) To begin the experiment, the density of Botrylloides sp. on each field panel was manipulated to produce one of 3 density treatment levels: control (C, $0 \%$ cover of Botrylloides sp.), low (L, ca $50 \%$ cover) and high ( $\mathrm{H}$, ca $75 \%$ cover $)$. Following these manipulations, all the panels were exposed to competent oyster larvae Crassostrea virginica in the laboratory which metamorphosed and attached in 12 to $15 \mathrm{~h}$ (Osman et al. 1989). After counting the number of oyster larvae which had settled, the panels were placed in $7.6 \mathrm{l}$ plastic containers which were three-quarters submerged in a large flowing seawater table at the Marine Sciences Institute, University of Connecticut. Each panel went into a separate container. The position of the containers in the seawater table was randomized. Each container was aerated and received a continuous flow of unfiltered seawater, pumped from Long Island Sound, except during algal addition periods (see below). Containers were cleaned every week to remove both organisms 
which had settled on the inside walls and debris which accumulated on the bottom.

There were 3 replicates each of 9 treatment combinations ( 3 density levels $\times 3$ food supply levels). Food supply was manipulated by exchanging a set volume of the seawater in each container with an aliquot of the same volume from algal cultures (primarily Isochrysis galbana T-ISO). The 3 food levels consisted of a control with no algae added, a $25 \%$ volume supplement and a $50 \%$ volume supplement of algal cultures (food levels 1 , 2 and 3 , respectively). Each feeding period lasted from 8 to $10 \mathrm{~h}$ and algae were added to experimental containers approximately every other day. Prior to adding algae, water flow into the containers was shut off and volumes of seawater were poured off corresponding to food treatment levels given above. This volume was then replaced from the algal culture. Air was kept bubbling in the containers throughout the experiment to ensure mixing during feeding periods and adequate oxygenation of the seawater. At the end of the feeding period, seawater flow into all the containers was reinitiated.

Algae were cultured out-of-doors in $345 \mathrm{l}$ tanks with semitransparent fiberglass walls. Algal cultures were started by half-filling the tanks with filtered (5 um) seawater and adding $12.5 \mathrm{~g}$ of NUSALTS (Algal Culturing Salts, Argent Chemical Laboratories), and a 11 inoculum of Isochrysis galbana. After $2 \mathrm{~d}$ the tank was topped up with filtered seawater. Algal inocula were maintained in the laboratory in 500 ml flasks using a modified Provasoli's culturing medium (Provasoli 1968).

Since algal concentrations in the cultures varied over time, concentrations in the experimental containers were sampled during the course of the experiment by obtaining $20 \mathrm{ml}$ water samples from randomly selected containers of each food level treatment. These samples were fixed using several drops of Lugol's solution, and algal counts were later made using a Sedgewick-Rafter counting chamber.

The experiment was initiated on July 13, 1987 and sampled 15 and $44 \mathrm{~d}$ afterwards. At each census, counts and size measurements of live oysters on the panels were made using a dissecting microscope at $16 x$ and $40 x$ fitted with an ocular micrometer. Also, qualitative observations were made on the coverage of Botrylloides sp. and other potentially competing species which had settled on the panels. Statjstical analyses, detailed in the results, were performed using SAS (1982).

\section{RESULTS}

Algal concentrations varied over the course of the experiment but differences between food level treatments were maintained (Fig. 1). With respect to competitor density treatments, however, coverage of Botryl-

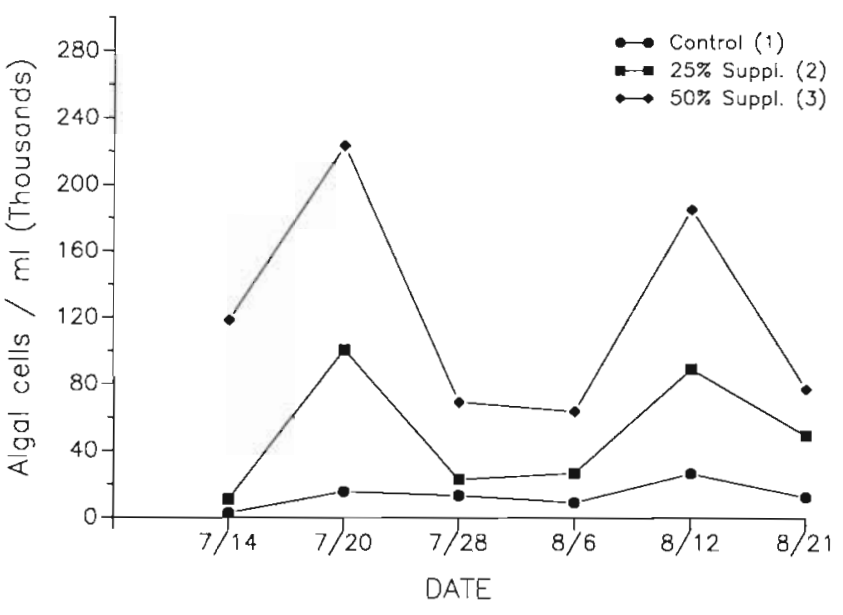

Fig. 1. Changes in algal concentrations in each of the feeding levels during the course of the experiment, July-August 1987. See text for feeding manipulation details

loides sp. decreased $50 \%$ on both $\mathrm{L}$ and $\mathrm{H}$ panels by Day 15 , and 75 to $100 \%$ by Day 44 . While Botrylloides coverage decreased, coverage by several other competing species (see Osman et al. 1989) increased, including the solitary ascidians Styela clava, Molgula manhatensis and Ciona intestinalis, and the arborescent bryozoan Bugula turrita, usually in proportion to the starting densities of Botrylloides. As such, overall competitor density levels (but not species identities) were roughly maintained during the experiment. Control panels always remained clear.

\section{Survivorship}

The mean percentage of newly settled oysters which survived to Day 15 was higher on control and low density panels which received algal additions (Fig. 2), but on

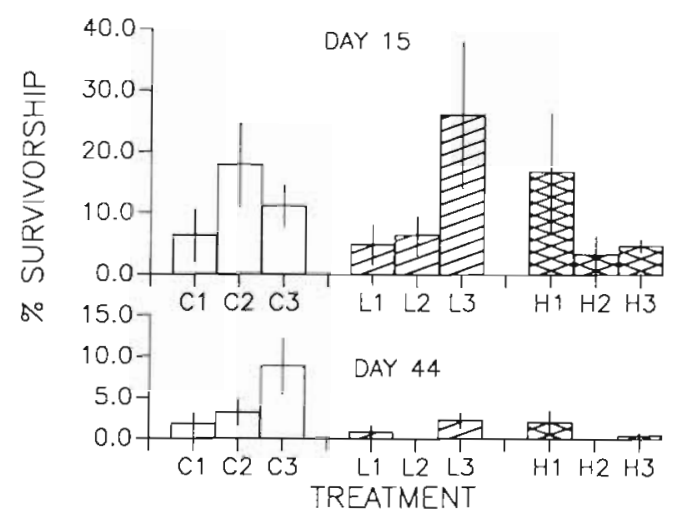

Fig. 2. Crassostrea virginica. Mean ( \pm 1 SE) percent survivorship of newly settled oysters in each of the treatments at Day 15 and Day 44 of the experiment. C, L, and $\mathrm{H}$ refer to control, low and high competitor density panels, respectively; 1,2 and 3 refer to control, $25 \%$ and $50 \%$ algal supplement treatments, respectively 
high density panels oyster survivorship was higher when no food was added (i.e. the H1 treatment). This same pattern was evident on Day 44, except that no oysters survived on $\mathrm{L} 2$ and $\mathrm{H} 2$ panels. Within density treatments, increasing food level had the strongest effects at Day 15 on low density panels and by Day 44 on control panels. At Day 44, survivorship on control panels was generally higher than on low and high density panels.

An overall analysis of variance (ANOVA) indicated that density, food, and time effects on oyster survivorship were significant (Table 1). Interactions between main effects were not significant, except for the Density $\times$ Food interaction, suggesting their influences were not additive. Given this interaction, the data were further analyzed by testing density and food effects separately (Table 2). These indicated competitor density effects on oyster survivorship were statistically significant over the course of the experiment, but food effects were only marginally significant.

\section{Size}

On Day 15, differences in oyster size were not great between treatments, although the largest individuals were found on C3 panels which received a high algal supplement (Fig. 3). Within low density panels, oyster mean size was also slightly higher on L3 panels. Size differences between treatments were much more pronounced on Day 44. While there were no differences between zero and high food supplement treatments on low and high density Botrylloides sp. panels, oyster size increased sharply with increasing food on control panels. Between densities, oysters grew to larger sizes

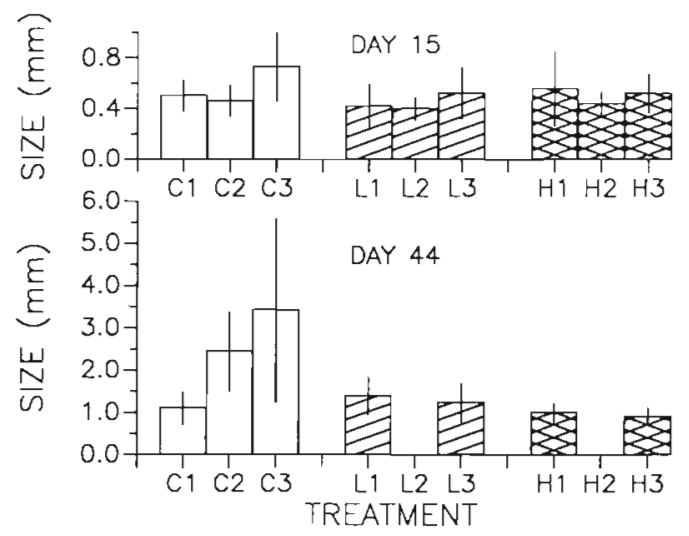

Fig. 3. Crassostrea virginica. Mean ( $\pm 1 \mathrm{SE})$ size of newly settled oysters at Day 15 and Day 44 of the experiment. Treatment designations as in Fig. 2

Table 1. Crassostrea virginica. Results of 3-way ANOVA of density, food and time effects on survivorship of newly settled oysters. Data were expressed as the \% individuals surviving of the total number which settled on a plate (see Osman et al 1989). Data were $\log (x+1)$ transformed prior to analysis to improve heterogeneity of variances. (Arcsine transformation, which is generally used for percentage data, increased variance differences between treatments due to large differences in the number of oysters which initially settled on the panels.) The analysis was performed using the GLM procedure in SAS (1982)

\begin{tabular}{|lccccc|}
\hline Source & Df & Type III SS & Mean Square & F-value & Pr>F \\
\hline Time & 1 & 20.98 & 20.98 & 32.28 & 0.0001 \\
Density & 2 & 6.07 & 3.04 & 4.67 & 0.0157 \\
Time $\times$ Density & 2 & 1.22 & 0.61 & 0.94 & 0.4012 \\
Food & 2 & 4.34 & 2.17 & 3.34 & 0.0467 \\
Time $\times$ Food & 2 & 0.21 & 0.10 & 0.16 & 0.8545 \\
Density $\times$ Food & 4 & 9.20 & 2.30 & 3.54 & 0.0155 \\
Time $\times$ Density $\times$ Food & 4 & 2.35 & 0.59 & 0.90 & 0.4730 \\
Error & 36 & 23.40 & 0.65 & & \\
\hline
\end{tabular}

Table 2. Crassostrea virginica. Results of separate 2-way ANOVA's for competitor-density and food effects on oyster survival

\begin{tabular}{|lcccrc|}
\hline Source & Df & Type III SS & Mean Square & F-value & Pr $>$ F \\
\hline Time & 1 & 3.96 & 3.96 & 25.58 & 0.0001 \\
Density & 2 & 1.15 & 0.57 & 3.69 & 0.0323 \\
Time $\times$ Density & 2 & 0.23 & 0.12 & 0.74 & 0.4824 \\
Error & 48 & 7.45 & 0.16 & 23.84 & 0.0001 \\
Time & 1 & 3.96 & 3.96 & 0.0956 \\
Food & 2 & 0.82 & 0.41 & 0.8902 \\
Time $\times$ Food & 2 & 0.04 & 0.02 & 0.16 & \\
Error & 48 & 7.45 & & & 0.12 \\
\hline
\end{tabular}


on C2 and C3 panels relative to sizes attained on any of the panels containing competing species.

Statistical analyses indicated that density, food and time effects on oyster size were significant (Table 3 ). However, all the interactions between main effects were significant. There were no significant differences in oyster size between replicates of treatments. Effects on oyster size were further analyzed by partitioning the data by treatment type and time of census (Table 4). Separate 1-way ANOVA's indicated both factors had significant effects on each date.

\section{DISCUSSION}

Results indicate that differences in both food supply and density of competitors can alter the survivorships and growth of newly settled oysters. Although these effects generally were statistically significant, there were no consistent trends over treatments, especially on the Day 15 census (Figs. 2 and 3). Mean survivorship of newly settled Crassostrea virginica was usually higher on control panels than on other panels, but high survivorship was also found on L3 and H1 panels.
Similar trends were generally evident with respect to oyster size on Day 15. The largest individuals were found on C3 panels, but growth was also high on L3, $\mathrm{H} 1$ and $\mathrm{H} 3$ panels, suggesting that increased food supply may have compensated for any competition effects (on the L3 and H3 panels) at least during this period following settlement. These mixed trends in early survivorship and growth may be due to differences in local conditions on the scale of a newly settled oyster's ambit.

Differences within and between treatments were more consistent and pronounced by Day 44. Both survivorship and size increased with increasing food supply on control panels, and $C 2$ and $C 3$ values were higher than low and high density values at each food level. Thus, as the oysters and resident species grew, the spatial scale of interactions may have increased yielding results that reflected general conditions over the experimental panel. It also appears that rather than continuing to mediate any density effects, increasing food exacerbated them with time. At increased food levels, co-occurring species on low and high density panels (primarily Styela clava and Ciona intestinalis by Day 44) grew to larger sizes (pers. obs.). We believe

Table 3. Crassostrea virginica. Results of 3-way ANOVA of density, food and time effects on growth of newly settled oysters. Differences between replicates was also tested. Sizes were $\log (x+1)$ transformed prior to analysis to reduce heterogeneity of variances. The analysis was performed using the GLM procedure in SAS (1982)

\begin{tabular}{|c|c|c|c|c|c|}
\hline Source & Df & Type III SS & Mean Square & F-value & $\operatorname{Pr}>F$ \\
\hline Replicates & 2 & 0.02 & 0.01 & 1.39 & 0.2512 \\
\hline Time & 1 & 1.01 & 1.01 & 136.98 & 0.0001 \\
\hline Density & 2 & 0.13 & 0.06 & 8.88 & 0.0002 \\
\hline Time $\times$ Density & 2 & 0.07 & 0.04 & 4.41 & 0.0133 \\
\hline Food & 2 & 0.05 & 0.03 & 3.03 & 0.0503 \\
\hline Time $\times$ Food & 2 & 0.05 & 0.03 & 3.42 & 0.0345 \\
\hline Density $\times$ Food & 4 & 0.18 & 0.05 & 6.13 & 0.0001 \\
\hline Time $\times$ Density $\times$ Food & 2 & 0.10 & 0.50 & 6.49 & 0.0019 \\
\hline Error & 205 & 1.51 & 0.01 & & \\
\hline
\end{tabular}

Table 4. Crassostrea virginica. Results of 1-way ANOVA's of competitor density and food effects on oyster growth for each sampling date

\begin{tabular}{|c|c|c|c|c|c|}
\hline Source & Df & Type III SS & Mean Square & F-value & $\operatorname{Pr}>F$ \\
\hline \multicolumn{6}{|l|}{ Day 15} \\
\hline Density & 2 & 0.181 & 0.091 & 5.52 & 0.0048 \\
\hline Error & 169 & 2.773 & 0.016 & & \\
\hline Food & 2 & 0.332 & 0.166 & 10.69 & 0.0001 \\
\hline Error & 169 & 2.622 & 0.015 & & \\
\hline \multicolumn{6}{|l|}{ Day 44} \\
\hline Density & 2 & 2.357 & 1.178 & 7.13 & 0.0019 \\
\hline Error & 48 & 7.928 & 0.165 & & \\
\hline Food & 2 & 1.409 & 0.705 & 3.81 & 0.0290 \\
\hline Error & 48 & 8.874 & 0.185 & & \\
\hline
\end{tabular}


that their higher food intake with increasing size progressively reduced the food available to oysters. This may explain the significant interactions that were found between density and food with respect to oyster growth. Thus, inherent differences in species growth rates (e.g. the slow growth of juvenile Crassostrea virginica versus that of juvenile solitary tunicates such as $S$. clava) may be an important determinant of the outcome of competition between fouling organisms, under particular food supply levels.

While densities of the initial competitor Botrylloides sp. decreased during the experiment, we attribute reductions in survivorship and growth of oyster between 15 and $44 \mathrm{~d}$ to the presence of the competing species which established and/or grew during the course of the experiment. Although their abundance and growth was not quantified, we believe that if they were not having a competitor effect then oyster survivorship and size would have begun to approximate control values for corresponding food levels.

Previous studies have shown that the early mortality of newly settled fouling species can be due to overgrowth, dislodgement from the substrate and/or predation (e.g. Keough \& Downs 1982, Davis 1987, Stocker \& Bergquist 1987, Osman et al. 1989). Results of this experiment suggest that food supply, and how that supply is affected by resident species, may also be an important determinant of recruitment success. Buss (1980) showed that competition for food between adult fouling organisms is important, being an extension of competition for space. Other studies suggest that competitive interactions between suspension feeders may be mediated via local food resource depletion (e.g. Buss \& Jackson 1981, Peterson \& Black 1987, and references therein). In this study, such interactions were primarily between newly settled oysters and adult and juvenile fouling species. Mortality resulting from overgrowth did not appear to be important in this experiment. Dead oysters were usually evident by empty shells, coverage by Botrylloides sp. decreased during the experiment, and higher densities of fouling organisms on $\mathrm{L}$ and $\mathrm{H}$ panels were due to the presence of solitary, suspension feeding species such as Styela clava and Molgula manhatensis. Thus, competition for food and fouling communities may occur over all life cycle stages and in the absence of limiting space, depending on food levels and the density and sizes of resident species.

In previous experiments we found that fouling organisms, including Botrylloides sp. and species with similar colony morphology, generally enhanced settlement of oyster larvae, but in some cases oyster mortality in the subsequent 1 to 3 mo was higher in the presence of such species relative to clean panels (Osman et al. 1989). This experiment indicates that the mean cause of post-settlement oyster mortality was local food depletion by co-occurring species. It also illustrates that interactions within fouling communities can change from positive to negative during the recruitment period.

While the importance of food supply level on growth and reproduction in suspension feeding bivalves is well known (e.g. Newell \& Bayne 1980, Bayne \& Newell 1983), and that established populations can deplete food resources both locally and over larger habitat areas (Peterson \& Black 1987), our results point to the importance of this factor to survivorship and growth of newly settled individuals. The quality and quantity of seston available to oyster populations, and fouling communities in general, varies on several spatial and temporal scales (Berg \& Newell 1986, and references therein). The range of algal concentrations in this study was typical of that found in the field (Conover 1956, Nixon \& Oviatt 1973, Mountford 1980). Population abundances of fouling species and the eventual size of individuals over unit time may therefore be determined not only by the effects varying food supply has on individuals following recruitment, but also by such conditions just following settlement.

Acknowledgements. L. Gypson, B. Lussier and R. Malatesta helped conduct the experiment. Algal starter cultures were provided by S. Cibik of The Benedict Estuarine Research Laboratory, The Environmental Research Laboratory (US Environmental Protection Agency, Narragansett) and National Marine Fisheries Laboratory (Milford CT), while C. Yarish, S. Cibik and J. Sanders provided helpful suggestions on culturing techniques. E. Rhodes (National Marine Fisheries Laboratory, Milford) provided the oyster larvae. To all our thanks. This work was supported by grants from The Cox Charitable Trust and the Connecticut Sea Grant Program. This is Contribution 218 from the Marine Sciences Institute of The University of Connecticut.

\section{LITERATURE CITED}

Bayne, B. L., Newell, R. C. (1983). Physiological energetics of marine molluscs. In: Saleuddin, A. S. M., Wilbur, K. M. (eds.) The Mollusca. Vol. 4 (1). Academic Press, New York, p. $407-415$

Berg, J. A., Newell, R. I. E. (1986). Temporal and spatial variations in the composition of seston available to the suspension feeder Crassostrea virginica. Estuar, coast. Shelf Sci. 23: 375-386

Bros, W. E. (1987). Effects of removing or adding structure (barnacle shells) on recruitment to a fouling community in Tampa Bay, Florida. J. exp. mar. Biol. Ecol. 105: 275-296

Buss, L. W. (1980). Bryozoan overgrowth interactions - the interdependence of competition for space and food. Nature, Lond. 281: 475-477

Buss, L. W., Jackson, J. B. C. (1981). Planktonic food availability and suspension feeder abundance: evidence of in situ depletion. J. exp. mar. Biol. Ecol. 49: 151-161

Butman, C. A. (1985). Larval settlement of soft-sediment invertebrates: the spatial scales of pattern explained by active habitat selection and the emerging rôle of hydro- 
dynamical processes. Oceanogr mar. Biol. A. Rev. 24 : 113-165

Conover, S. A. M. (1956). Oceanography of Long Island Sound, 1952-1954. IV Phytoplankton. Bull. Bingham. Oceanogr. Coll. 15: 62-112

Davis, A. R. (1987). Variation in recruitment of the subtidal colonial ascidian Podoclavella cylindrica (Quoy \& Gaimard): the role of substratum choice and early survival. J. exp. mar Biol. Ecol. 106: 57-71

Dean, T A. (1981). Structural aspects of sessile invertebrates as organizing forces in an estuarine fouling community J. exp. Mar. Biol. Ecol. 36: 269-294

Dean, T A., Hurd, T E. (1980). Development in an estuarine fouling community: the influence of early colonists on later arrivals. Oecologia (Berl.) 46: 295-301

Gaines, S., Brown, S., Roughgarden, J. (1985). Spatial variation in larval concentrations as a cause of spatial variation in settlement for the barnacle, Balanus glandula. Oecologia (Berl.) 67: 267-272

Gallagher, E. D., Jumars, P. A., Trueblood, D. D. (1983) Facilitation of soft-bottom benthic succession by tube builders. Ecology 64: 1200-1216

Ketchum, B. H. (1954). Relation between circulation and planktonic populations in estuaries. Ecology 35: 191-200

Keough, M. J. (1983). Patterns of recruitment of sessile invertebrates in two subtidal habitats. J. exp. mar. Biol. Ecol. 66 : 213-245

Keough, M. J., Downes, B. J. (1982). Recruitment of marine invertebrates: the role of active larval choices and early mortality. Oecologia (Berl.) 54: 348-352

Mountford, K. (1980). Aspects of the ecology of a small estuarine embayment. Mar Biol 61. 53-67

Newell, R. I. E., Bayne, B. L. (1980). Seasonal changes in the physiology, reproductive condition and carbohydrate con-

This article was submitted to the editor tent of the cockle Cardium (= Cerastoderma) edule (Bivalvia: Cardiidae). Mar. Biol. 56: 11-19

Nixon, S. W. Oviatt, C. A. (1973). Ecology of a New England salt marsh. Ecol. Monogr. 43: 463-498

Osman, R., Whitlatch, R. B., Zajac, R. N. (1989). Effects of resident species on recruitment into a community: larval settlement versus post-settlement mortality in the oyster Crassostrea virginica. Mar. Ecol. Prog. Ser. 54: 61-73

Peterson, C. H., Black, R. (1987). Resource depletion by active suspension feeders on tidal flats: influence of local density and tidal elevation. Limnol. Oceanogr. 32: 143-166

Provasoli, L. (1968). Media and prospects for the cultivation of marine algae. In: Watanabe, A., Hattorii, A. (eds.) Cultures and collections of algae. Proc. US - Japan Conf. Hakone, September 1966. Jap. Soc. Plant Physiol, p. 63-75

Roughgarden, J., Iwasa, Y., Baxter, C. (1985). Demographic theory for an open marine population with space-limited recruitment. Ecology 66: 54-67

SAS (1982). SAS users guide: statistics. SAS Institute, Carey, North Carolina

Stocker, L. J., Bergquist, P. R. (1987). Importance of algal turf, grazers, and spatial variability in the recruitment of a subtidal colonial invertebrate. Mar. Ecol. Prog. Ser 39: $285-291$

Sutherland, J. P., Karlson, R. H. (1977). Development and stability of the fouling community at Beaufort, North Carolina. Ecol. Monogr. 47: 425-446

Whitlatch, R. B., Zajac, R. N. (1985). Biotic interactions among estuarine infaunal opportunistic species. Mar. Ecol. Prog. Ser. 21: 299-311

Woodin, S. A. (1985). Effects of defecation by arenicolid polychaete adults on spionid polychaete juveniles in field experiments: selective settlement or differential mortality. J. exp. mar. Biol. Ecol. 87: 119-132

Manuscript first received: December 13, 1988

Revised version accepted: May 26, 1989 